\title{
Audit Committee Accounting Expert and Earnings Management with "Status" Audit Committee as Moderating Variable
}

\section{Edy Suprianto ${ }^{1 *}$, Suwarno Suwarno², Henny Murtini³, Rahmawati Rahmawati ${ }^{4}$, Dyah Sawitri ${ }^{5}$}

${ }^{1}$ Universitas Islam Sultan Agung, Department of Accounting, Semarang, Indonesia ${ }^{2}$ STIE Purna Graha, Department of Accounting, Pekanbaru, Indonesia 3 Universitas Negeri Semarang, Department of Accounting, Semarang, Indonesia ${ }^{4}$ Universitas Sebelas Maret, Department of Accounting, Surakarta, Indonesia ${ }^{5}$ Universitas Gajayana Malang, Department of Management, Malang, Indonesia

*Correspondence to: Edy Suprianto, Universitas Islam Sultan Agung, Department of Accounting, Jalan Kaligawe km 4, Semarang 50112, Indonesia.

E-mail: edy_2806@yahoo.co.id

\begin{abstract}
This research aims to analyze the effect of accounting expert of audit committee on earnings management. This research also assesses the role of audit committee on earnings management with audit committee status as moderating variable. The population is all of firm's which listed in Indonesia Stock Exchange. Purposive sampling is used to collect data. Data used financial statements and annual report companies from Indonesia Stock Exchange website. Moderated regression analysis (MRA) is used to analyze the hypothesis. The result shows that accounting expert of audit committee has negative effect on earnings management. Yet, variable of audit committee status cannot moderate the relationship between accounting expert of audit committee and earnings management in Indonesia.
\end{abstract}

Keywords: status, accounting expert of audit committee, earnings management.

Article info: Received 16 August 2017; revised 20 October 2017; accepted 28 November 2017

Recommended citation: Suprianto, E., Suwarno, S., Murtini, H., Rahmawati, R., \& Sawitri, D. (2017). Audit Committee Accounting Expert and Earnings Management with "Status" Audit Committee as Moderating Variable. Indonesian Journal of Sustainability Accounting and Management, 1(2), 49-58.

DOI: 10.28992/ijsam.v1i2.16

\section{Introduction}

Based on statistical data, the practice of earnings management in Indonesia is increasing. In 2002, Lippo Bank practiced earnings management to cover losses of 1.273 trillion rupiahs through changes in estimates of the value of foreclosed properties and on allowance for possible losses on earning assets (Butar, 2014). Widyawati \& Anggraita (2013) recorded that the average magnitude of discretionary accruals of companies listed in Indonesia Stock Exchange in 2011 was greater than the average number of discretionary accruals in 2010. Butar (2014) also noted that the absolute abnormal accruals value increased from the average of 5.84\% in 2001-2003 to $6.27 \%$ in 2004-2010 and it indicates that the practice of earnings management has been increasing every year.

This increase in earnings management case prompted the Capital Market Supervisory Agency (Bapepam) to issue a Decree of the Chairman of Bapepam. Kep-29/PM/2004 on the obligations for companies listing on BEI 
to have audit committee. The research discussing about the importance of the audit committee in preventing the opportunistic acts of management varies considerably. For example, Abbott et al. (2004) examined the effectiveness of the audit committee on financial statement restatement, while Krishnan \& Visvanathan (2008) examined the existence of audit committees on conservatism accounting. Moreover, Chandar et al. (2012) \& Chen et al. (2007) conducted a research on the effect of audit committee on earnings management. Lately, some studies are now focusing more on the effectiveness of audit committees in terms of expertise and experience such as Badolato et al. (2014); Abernathy et al. (2014); Sun et al. (2014); Cohen et al. (2014). This study focuses more on earnings management in a country that has common problems on agency between controlling and non-controlling shareholders (Fan \& Wong, 2002); (Gunardi \& Widyaningsih, 2017) in the form of entrenchment as tunneling (Habib et al., 2017). The behavior of tunneling is rarely studied in Indonesia and it motivates the researcher to conduct research in Indonesia.

The importance of expert audit committee within the firm has been suppressed by the Sarbanes-Oxley Act (2002) that the audit committee should have experience and accountability in financial and accounting fields (Beasley et al., 2009; J. R. Cohen et al., 2014). In some countries, such as Canada in the joint committee on corporate governance (Niu, 2006), in Russian with the Corporate Governance Code (Ahmed, 2013) and in Malaysia with the Malaysian code on corporate governance (Saleh et al., 2007) also stated the same thing on the purpose of improving the audit committee's performance in a public firm. While in Indonesia, in 2000, the Capital Market and Financial Reporting Agency (Bapepam LK) also issued a regulation on the obligation of public corporations to have an audit committee with experience and expertise on accounting and financial field.

Some researchers found that the audit committee expert has a significant negative effect on earnings management, such as concluded by Carcello \& Neal (2003); Saleh et al. (2007); Kang et al. (2011); Siagian \& Tresnaningsih (2011); Nelson \& Devi (2013); Chandar et al. (2012); Zgarni et al. (2016). On the other hand, several other studies stated that the audit committee expert has no significant negative effect on earnings management such as research by Chen et al. (2005); Cohen et al. (2007); Sun et al. (2014); Yunos et al. (2014).

The status of the audit committee within the firm exerts an influence on management. In the study by Badolato et al. (2014), it has been stated that the status of audit committee will be able to strengthen its role in monitoring the opportunistic behavior of management in practicing earnings management. It is assumed that high-level audit committees have better competence and authority because they have a static position with a credibility and a high level of respect (D'Aveni, 1990; Pollock et al., 2010). In addition, the high audit committee status tends to have more comprehensive monitoring and information experience.

According to Badolato et al. (2014) study, we interested to retest their model in Indonesia. We choose Indonesia because it including country with emerging market which has difference characteristic compare with US regarding with ownership structures. This study provides some contributions, among others is first, it provides empirical research evidence on the type of earnings management practices in accordance with capital market conditions in Indonesia. Second, it provides empirical evidence about the influence of accounting expert for the audit committee on earnings management. Third, this study can add literature on the role of audit committees in monitoring the firm's financial statements related to its status within the firm. To answer these questions, this study retrieved the data from the website of Indonesia Stock Exchange (BEI) in the form of financial statements and annual report in 2015. The samples obtained in this study were as many as 203 companies.

In the agency theory, it is stated that the owner or shareholder cannot supervise the management behavior within the firm that always tends to be opportunistic (Jensen \& Meckling, 1976). Therefore, it is necessary to have monitoring mechanisms to inform stakeholders that the firm's financial statements are correct (Asmeri et al., 2017; Defond et al., 2005; Jones et al., 2017; A. Rokhmawati \& Gunardi, 2017; Rokhmawati 
et al., 2017). Krishnan \& Visvanathan (2008) argued that the audit committee directors with expertise coined the best ability to distinguish some accounting policies (as conservative or aggressive), and they have more incentive than other directors.

In the Decree of the Chairman of Bapepam. Kep-29/PM/2004, it is explained that the members of the audit committee must have at least an expert or experience and expertise in accounting and finance. It is said a financial expert has an understanding of GAAP and financial statement, can access accounting application of a firm, understand task and audit committee function and have experience in auditing, preparing, analyzing, and evaluating financial report (Gunardi, 2014).

Some researchers found that audit committee experience has a negative significant effect on earnings management, such as Saleh et al. (2007); Kang et al. (2011); Siagian \& Tresnaningsih (2011); Nelson \& Devi (2013); Chandar et al. (2012); Zgarni et al. (2016). It is described in agency theory (Jensen \& Meckling, 1976) that the audit committee as a corporate governance mechanism has expertise to evaluate management financial statements. The more experienced audit committees (expert in accounting, finance, business industry and so on) will be more effective in reviewing the financial reporting (Sun et al., 2014) for having proper knowledge and experience to detect earnings management practice (Liu et al., 2013; Suteja et al., 2016).

The existence of audit committee as a good corporate governance mechanism will reduce the practice of earnings management done by the agent. Nelson \& Devi (2013) stated that there is a negative correlation between the audit committee and earnings management. This is supported by Inaam \& Khamoussi (2016) that there is a negative effect of the audit committee (which is proxied with the independence of the audit committee, audit committee meeting frequency, size and expertise of the audit committee) on earnings management.

Research on the role of audit committees in reducing earnings management practices has been largely undertaken by many previous researchers. Some of them have asserted that the audit committee has a negative effect on earnings management, such as Nelson \& Devi (2013); Zgarni et al. (2016); Chandar et al. (2012). Stated that accounting expert and non-accounting expert have negative significant effect on earnings management, while financial expert and non-accounting professional expert have positive insignificant effect on earnings management. Nelson \& Devi (2013) by using Resources Dependent Theory (RDT) added that the measurement of audit committee expert by dividing into 4 categories of expertise i.e. accounting expert, financial expert, non-accounting professional expert and non-accounting expert. This is in line with Sarbanes Oxley Act (2002), Blue Ribbon Committee (1999) and code of corporate governance.

There are several reasons why status must be taken into account. First, audit committee with higher status will be considered to have more competence (D’Aveni, 1990; Pollock et al., 2010). Second, audit committee with a relatively high status will be able to do monitoring more actively and need comprehensive information (Rahmawati et al., 2017). Status and the correlation of the concepts are something important in several settings of a firm, even when someone has high incentive to do monitoring. In other words, it can be said that a director who has low power will get compensation lower than the one with high power (Belliveau et al., 1996); (Grinstein \& Hribar, 2004), moreover if the director has bad reputation or performance (Bebchuk et al., 2002). There is a direct effect of status attached by an audit committee toward the manager, because it perceives ability and authority of someone (D'Aveni, 1990; Pollock et al., 2010). Badolato et al. (2014) also found that status of audit committee can strengthen their position in preventing opportunistic behavior of management in conducting earnings management. 


\section{Methods}

This study involved all go public firms in Indonesia excluding bank and financial companies including leasing and insurance because they have different characteristics. The sample in this study was selected through purposive sampling method with the following criteria: First, the firm reports its financial statement for 2015 period. Second, the firm should have all data for measuring all variables in this study. The data in this study were obtained from Indonesia Stock Exchange website in form of financial statement and annual report 2015.

Earnings management as dependent variable in this study was measured by using a model which was done by most researchers in the countries with emerging market, i.e. (Lo \& Wong, 2011) model with linearity:

$$
R L P T=\alpha+\beta 1 L E V+\beta 2 S I Z E+\beta 3 M K V E+\beta 4 I N D+\varepsilon \ldots \text { (1) }
$$

Where:

RLPT = Transaction with third party

LEV = Total of liability divided with total of asset

SIZE = Firm size (total asset)

MKVE = Value of equity market divided with value of equity book

IND = Dummy variable for industrial type of firm

We used value of residual of first equation to measure earning management variable. The independent variable in this study was accounting expert audit committee which was measured with the percentage of total members of audit committee who have expertise and experience in accounting (Abernathy et al., 2014). While the status variable became the moderating variable in this study which was measured through the percentage of total member of audit committee who have high status such as public boards group, private boards group, and elite education (Badolato et al., 2014).

This study employed multiple regression with regression linearity:

$$
E M=a+b 1 A C E+b 2 S T A T+b 3 A C E * S T A T+b 4 S I Z E+b 5 L E V+\varepsilon \ldots(2)
$$

Where:

$\mathrm{EM} \quad=$ Earnings management variable

ACE $=$ Accounting expert audit committee variable

STAT = Status variable

ACE*STAT = The interaction of accounting expert audit committee variable and status variable

Table 1 Distribution of Sample

\begin{tabular}{llcc}
\hline No. & \multicolumn{1}{c}{ Variable } & Obs. & Percentage \\
\hline 1. & Agriculture \& Mining & 31 & $15 \%$ \\
2. & Basic \& Chemicals Industry & 39 & $16 \%$ \\
3. & Miscellaneous \& Consumer Goods Industry & 40 & $20 \%$ \\
4. & Property, Real Estate and Building Construction & 25 & $12 \%$ \\
5. & Infrastructure, Utilities and Transportation & 34 & $15 \%$ \\
6. & Trade, Services \& Investment & 43 & $22 \%$ \\
& Total & 203 & $100 \%$ \\
\hline
\end{tabular}




\section{Results and Discussion}

Based the sampling technique, it obtained 203 firms as sample in this study. In table 1 we divided these samples based on each industry. From 203 samples consists of 31 firms included agriculture and mining industry, basic \& Chemicals Industry about 39 firms, Miscellaneous \& Consumer Goods Industry about 40 firms, Property, Real Estate and Building Construction industry about 25 firms, Infrastructure, Utilities and Transportation industry 34 firms and industry of Trade, Services \& Investment 43 firms. So, we can conclude that the biggest sample is industry of Trade, Services \& Investment and the smallest samples from industry of Property, Real Estate and Building Construction.

Table 2 Statistic Descriptive

\begin{tabular}{|c|c|c|c|c|}
\hline No. & Variable & Obs. & Mean & Std. Dev \\
\hline 1. & EM & 203 & 0.065 & 1.434 \\
\hline 2. & ACE & 203 & 0.235 & 0.28 \\
\hline 3. & STAT & 203 & 0.365 & 0.48 \\
\hline 4. & SIZE & 203 & 0.527 & 0.419 \\
\hline 5. & LEV & 203 & 28.8 & 1.66 \\
\hline
\end{tabular}

Table 2 shows the statistic descriptive of each variable. Accounting expert audit committee variable resulted average value of 0.235 . This means that most of the firms which became the sample in this study had knowledge and expertise in accounting i.e. 1 member if total member of audit committee as much as 3 people. The status of audit committee variable resulted 0.365 , meaning that few audit committees working in manufacturing industries which became sample in this study had a relatively low status. Tunneling variable as a proxy of earnings management resulted 0.065 . This value was positive so that it occurred opportunistic behavior of shareholders in conducting tunneling (Badolato et al., 2014). Even though this value is low, however, it indicates that the majority of shareholders tends to do earnings management by expropriation (Fan \& Wong, 2002).

This research cannot give evidence that status give positive effect on role of audit committee to prevent manager do earnings management. This is because the status of audit committee was very low so that it could not give big effect on management to not do earnings management. Besides, it might be affected by the age of audit committee where most of them were old enough, so that it made their activity limited. We can look at the descriptive of variable especially for status in Table 2, show mean of status variable about 0.365 . Although this number is not small but after look at profile of audit committee in a firm annual report shows that their age more than 60 years old. This age is nonproductive time, while they have more experience.

From Table 3, it can be seen in first model that coefficient value of accounting expert audit committee variable resulted -0.425 with probability level of $1 \%$. Because of the significance level less than $5 \%$ so we can suggest that accounting expert audit committee has negative significant effect on earnings management in Indonesia. Thus, first hypothesis was accepted. We also can see on control variable size has negative effect on earnings management, while leverage has positive effect on earnings management but not significantly. This result also was supported by regression analysis for industry-based in Table 4 (except for trade, service and investment industry). Therefore, it can be concluded that the hypothesis 1 was approved, meaning that accounting expert audit committee has negative significant effect at $1 \%$ level on earnings management in 
Indonesia. Furthermore, the existence of accounting expert audit committee would reduce opportunistic behavior of management in conducting earnings management.

Table 3 Panel A Full Sample

\begin{tabular}{lccc}
\hline \multicolumn{1}{c}{ Independent Variable } & Predict Sign. & $\begin{array}{c}\text { Dependent Variable: } \\
\text { Earnings Management }\end{array}$ & $\begin{array}{c}\text { Dependent Variable: } \\
\text { Earnings Management }\end{array}$ \\
\cline { 2 - 4 } Constant & $?$ & $-0.160^{* * *}$ & -0.117 \\
ACE & - & $-0.425^{* * *}$ & $-0.453^{* * *}$ \\
STAT & - & & 0.056 \\
ACE*STAT & - & & -0.115 \\
Control Variable: & & & \\
SIZE & + & -0.006 & -0.005 \\
LEV & 0.003 & 0.001 \\
Total Obs. & 203 & 203 \\
Adjusted $R^{2}$ & 0.114 & 0.108 \\
F (Statistics) & 0.669 & 5.789 \\
Probability & & 0.000 & 0.000 \\
\hline
\end{tabular}

*significant at level $10 \%, * *$ significant at level $5 \%$ and $* * *$ significant at level $1 \%$

This result supports previous research which conducted by Nelson \& Devi (2013); Zgarni et al. (2016); Chandar et al. (2012) stated that Accounting Expert Audit Committee has negative effect on earnings management. Thus, the existence of audit committee who has accounting skill will reduce opportunistic manager in firm to conduct earnings management. Accounting expert audit committee has expertise to evaluate management financial statements and has more experienced in accounting, finance, business industry and so on. They will be more effective in reviewing the financial reporting process (Sun et al., 2014) for having proper knowledge and experience to detect earnings management practice (Liu et al., 2013). They will provide recommendations to the board of commissioners about the information produced by the manager before being used by shareholders in decision making (Honggowati et al., 2017). So, it is evidence that accounting expert audit committee is important in corporate as good corporate governance mechanism.

From Table 3 we also can be seen on second model that coefficient value of accounting expert audit committee variable was -0.453 with probability level of $1 \%$. Therefore, this finding is still in line with the hypothesis 1. Besides, it also can be seen that the coefficient value of the interaction of accounting expert audit committee variable \& status variable resulted -0.115 with probability level of over $5 \%$. So, it can be concluded that the hypothesis 2 was rejected, meaning that the interaction of those two variables has no effect on earnings management level in Indonesia. In Table 3 we also can see that coefficient value of the status variable resulted 0.056 with probability level of over $5 \%$. This research contrast with previous study which conducted by Badolato et al. (2014) found that status of audit committee can strengthen their position in preventing opportunistic behavior of management in conducting earnings management. 
Table 4 Panel B Industry-Based

\begin{tabular}{|c|c|c|c|c|c|c|c|}
\hline \multirow[t]{2}{*}{$\begin{array}{l}\text { Independent } \\
\text { Variable }\end{array}$} & \multirow[t]{2}{*}{$\begin{array}{l}\text { Predict } \\
\text { Sign. }\end{array}$} & \multicolumn{2}{|c|}{ Agriculture \& Mining } & \multicolumn{2}{|c|}{$\begin{array}{l}\text { Basic \& Chemicals } \\
\text { Industry }\end{array}$} & \multicolumn{2}{|c|}{$\begin{array}{c}\text { Miscellaneous \& Consumer } \\
\text { Goods Industry }\end{array}$} \\
\hline & & (1) & (2) & (1) & (2) & (1) & (2) \\
\hline Constant & $?$ & -0.030 & -0.173 & -0.373 & -0.026 & 0.577 & 0.620 \\
\hline ACE & - & $-0.490 * * *$ & $-0.516 * * *$ & $-0.545^{* * *}$ & $-0.567^{* * *}$ & $-0.147^{* *}$ & $-0.146 * *$ \\
\hline STAT & - & & 0.140 & 0.065 & 0.053 & & 0.018 \\
\hline ACE*STAT & - & & -0.237 & 0.071 & -0.237 & & $0.004^{*}$ \\
\hline \multicolumn{8}{|l|}{$\begin{array}{l}\text { Control } \\
\text { Variable: }\end{array}$} \\
\hline SIZE & - & -0.047 & -0.059 & & 0.0731 & -0.045 & -0.046 \\
\hline LEV & + & -0.007 & -0.002 & & -0.031 & $-0.022 * *$ & $-0.024^{* *}$ \\
\hline Total Obs. & & 31 & 31 & 33 & 33 & 40 & 40 \\
\hline Adjusted $\mathrm{R}^{2}$ & & 0.250 & 0.190 & 0.259 & 0.221 & 0.203 & 0.161 \\
\hline F (Statistics) & & 4.347 & 2.943 & 5.446 & 3.162 & 4.328 & 2.504 \\
\hline Probability & & 0.012 & 0.031 & 0.003 & 0.019 & 0.010 & 0.049 \\
\hline
\end{tabular}

Table 4 Panel B Industry-Based (Continued)

\begin{tabular}{|c|c|c|c|c|c|c|c|}
\hline \multirow[t]{2}{*}{$\begin{array}{l}\text { Independent } \\
\text { Variable }\end{array}$} & \multirow[t]{2}{*}{$\begin{array}{l}\text { Predict } \\
\text { Sign. }\end{array}$} & \multicolumn{2}{|c|}{$\begin{array}{l}\text { Property, Real Estate and } \\
\text { Building Construction }\end{array}$} & \multicolumn{2}{|c|}{$\begin{array}{l}\text { Infrastructure, Utilities } \\
\text { and Transportation }\end{array}$} & \multicolumn{2}{|c|}{ Trade, Services \& Investment } \\
\hline & & (1) & (2) & (1) & (2) & (1) & (2) \\
\hline Constant & ? & 0.749 & 0.906 & -0.077 & 0.683 & -6.894 & -1.895 \\
\hline ACE & - & $-0.656 * * *$ & $-0.228 * * *$ & $-0.574^{* *}$ & $-0.243^{* *}$ & -0.275 & -0.215 \\
\hline STAT & - & & 0.053 & & -0.039 & & -0.173 \\
\hline ACE*STAT & - & & 1.086 & & 1.079 & & 0.218 \\
\hline $\begin{array}{l}\text { Control } \\
\text { Variable: }\end{array}$ & & & & & & & \\
\hline SIZE & - & $-0.412 *$ & $-0.079 *$ & $-0.008 *$ & $0.001 *$ & -0.074 & -0.094 \\
\hline LEV & + & $-0.025^{* *}$ & $-0.035^{* *}$ & $-0.004^{*}$ & $-0.030 *$ & 2.021 & 0.068 \\
\hline Total Obs. & & 25 & 25 & 31 & 31 & 43 & 43 \\
\hline Adjusted $\mathrm{R}^{2}$ & & 0.291 & 0.596 & 0.043 & 0.247 & 0.020 & 0.103 \\
\hline F (Statistics) & & 4.2861 & 8.108 & 1.362 & 2.570 & 1.291 & 0.850 \\
\hline Probability & & 0.0169 & 0.000 & 0.281 & 0.061 & 0.290 & 0.523 \\
\hline
\end{tabular}

*significant at level $10 \%, * *$ significant at level $5 \%$ and $* * *$ significant at level $1 \%$ 


\section{Conclusion}

This study suggests that accounting expert of audit committee has negative effect on earnings management. Yet, variable of audit committee status cannot moderate the relationship between accounting expert of audit committee and earnings management in Indonesia. Status cannot support accounting expert of audit committee effectiveness because might be affected by the age of audit committee where most of them were old enough, so that it made their activity limited. So, our findings imply that increasing accounting expert of audit committee is effective without considering status. Our findings are important to firms which listed in Indonesia Stock Exchange to consider have audit committee accounting expert. This research just takes sample one years, so future study can use longer period. We also limited by status measurements, future study can explore the better measurement of audit committee status.

\section{References}

Abbott, L. J., Parker, S., \& Peters, G. F. (2004). Audit Committee Characteristics and Restatements. Auditing: A Journal of Practice and Theory, 23(1), 69-87. http://doi.org/10.2308/aud.2004.23.1.69

Abernathy, J. L., Beyer, B., Masli, A., \& Stefaniak, C. M. (2014). The association between characteristics of audit committee accounting experts, audit committee chairs, and financial reporting timeliness. Advances in Accounting, 30(2), 283-297. http://doi.org/10.1016/j.adiac.2014.09.001

Ahmed, S. (2013). Measuring quality of reported earnings' response to corporate governance reforms in Russia. Journal of Accounting in Emerging Economies, 3(1), 21-46. http://doi.org/10.1108/20440831311287682

Asmeri, R., Alvionita, T., \& Gunardi, A. (2017). CSR Disclosures in the Mining Industry: Empirical Evidence from Listed Mining Firms in Indonesia. Indonesian Journal of Sustainability Accounting and Management, 1(1), 16 22. http://doi.org/10.28992/ijsam.v1i1.23

Badolato, P. G., Donelson, D. C., \& Ege, M. (2014). Audit committee financial expertise and earnings management: The role of status. Journal of Accounting and Economics, 58(2-3), 208-230. http://doi.org/10.1016/j.jacceco.2014.08.006

Beasley, M. S., Carcello, J. V., Hermanson, D. R., \& Neal, T. L. (2009). The Audit Committee Oversight Process. Contemporary Accounting Research, 26(1), 65-122. http://doi.org/10.1506/car.26.1.3

Bebchuk, L. A., Fried, J. M., \& Walker, D. I. (2002). Managerial Power and Rent Extraction in the Design of Executive Compensation. The University of Chicago Law Review, 69(3), 751. http://doi.org/10.2307/1600632

Belliveau, M. A., O'Reilly III, C. A., \& Wade, J. B. (1996). Social Capital at the Top: Effects of Social Similarity and Status on CEO Compensation. Academy of Management Journal, 39(6), 1568-1593. http://doi.org/10.2307/257069

Butar, S. B. (2014). Implikasi Regulasi Pasar Modal terhadap Motif Manajemen Laba: Pengujian Berbasis Teori Pensinyalan. Jurnal Akuntansi Dan Keuangan Indonesia, 11(1), 99-119.

Carcello, J. V., \& Neal, T. L. (2003). Audit Committee Characteristics and Auditor Dismissals following "New" Going-Concern Reports. The Accounting Review, 78(1), 95-117. http://doi.org/10.2308/accr.2003.78.1.95

Chandar, N., Chang, H., \& Zheng, X. (2012). Does overlapping membership on audit and compensation committees improve a firm's financial reporting quality? Review of Accounting and Finance, 11(2), 141-165. http://doi.org/10.1108/14757701211228192

Chen, K. Y., Elder, R. J., \& Hsieh, Y.-M. (2007). Corporate Governance and Earnings Management: The Implications of Corporate Governance Best-Practice Principles for Taiwanese Listed Companies. Journal of Contemporary Accounting \& Economics, 3(2), 73-105. http://doi.org/10.1016/S1815-5669(10)70024-2

Chen, K. Y., Lin, K., \& Zhou, J. (2005). Audit quality and earnings management for Taiwan IPO firms. Managerial Auditing Journal, 20(1), 86-104. http://doi.org/10.1108/02686900510570722 
Cohen, J., Gaynor, L. M., Krishnamoorthy, G., \& Wright, A. M. (2007). Auditor Communications with the Audit Committee and the Board of Directors: Policy Recommendations and Opportunities for Future Research. Accounting Horizons, 21(2), 165-187. http://doi.org/10.2308/acch.2007.21.2.165

Cohen, J. R., Hoitash, U., Krishnamoorthy, G., \& Wright, A. M. (2014). The Effect of Audit Committee Industry Expertise on Monitoring the Financial Reporting Process. The Accounting Review, 89(1), 243-273. http://doi.org/10.2308/accr-50585

D’Aveni, R. A. (1990). Top Managerial Prestige and Organizational Bankruptcy. Organization Science, 1(2), 121142. http://doi.org/10.1287/orsc.1.2.121

Defond, M. L., Hann, R. N., \& Hu, X. (2005). Does the Market Value Financial Expertise on Audit Committees of Boards of Directors? Journal of Accounting Research, 43(2), 153-193. http://doi.org/10.1111/j.1475679x.2005.00166.x

Fan, J. P. H., \& Wong, T. J. (2002). Corporate ownership structure and the informativeness of accounting earnings in East Asia. Journal of Accounting and Economics, 33(3), 401-425. http://doi.org/10.1016/S01654101(02)00047-2

Grinstein, Y., \& Hribar, P. (2004). CEO compensation and incentives: Evidence from M\&A bonuses. Journal of Financial Economics, 73(1), 119-143. http://doi.org/10.1016/j.jfineco.2003.06.002

Gunardi, A. (2014). The Implementation of UEFA Financial Fair Play: An Analysis of Financial Performance of Manchester United. International Journal of Science and Research , 3(10), 612-620.

Gunardi, A., \& Widyaningsih, I. U. (2017). The Influence of Cash Flow Right, Control Right, and Cash Flow Right Leverage of the Controling Shareholders on Firm Value in Indonesia. Indian Journal of Economics and Development, 13(2), 321-326. http://doi.org/10.5958/2322-0430.2017.00182.2

Habib, A., Muhammadi, A. H., \& Jiang, H. (2017). Political Connections and Related Party Transactions: Evidence from Indonesia. The International Journal of Accounting, 52(1), 45-63. http://doi.org/10.1016/j.intacc.2017.01.004

Honggowati, S., Rahmawati, R., Aryani, Y. A., \& Probohudono, A. N. (2017). Corporate Governance and Strategic Management Accounting Disclosure. Indonesian Journal of Sustainability Accounting and Management, 1(1), 23-30. http://doi.org/10.28992/ijsam.v111.24

Inaam, Z., \& Khamoussi, H. (2016). Audit committee effectiveness, audit quality and earnings management: a meta-analysis. International Journal of Law and Management, 58(2), 179-196. http://doi.org/10.1108/IJLMA01-2015-0006

Jensen, M. C., \& Meckling, W. H. (1976). Theory of the firm: Managerial behavior, agency costs and ownership structure. Journal of Financial Economics, 3(4), 305-360. http://doi.org/10.1016/0304-405X(76)90026-X

Jones, P., Wynn, M., Hillier, D., \& Comfort, D. (2017). The Sustainable Development Goals and Information and Communication Technologies. Indonesian Journal of Sustainability Accounting and Management, 1(1), 1-15. http://doi.org/10.28992/ijsam.v111.22

Kang, W. S., Kilgore, A., \& Wright, S. (2011). The effectiveness of audit committees for low- and mid-cap firms. Managerial Auditing Journal, 26(7), 623-650. http://doi.org/10.1108/02686901111151341

Krishnan, G. V., \& Visvanathan, G. (2008). Does the SOX Definition of an Accounting Expert Matter? The Association between Audit Committee Directors' Accounting Expertise and Accounting Conservatism. Contemporary Accounting Research, 25(3), 827-858. http://doi.org/10.1506/car.25.3.7

Liu, J., Harris, K., \& Omar, N. (2013). Board Committees and Earnings Management. Corporate Board: Role, Duties and Composition, 9(1), 6-17.

Lo, A. W. Y., \& Wong, R. M. K. (2011). An empirical study of voluntary transfer pricing disclosures in China. Journal of Accounting and Public Policy, 30(6), 607-628. http://doi.org/10.1016/j.jaccpubpol.2011.08.005 
Nelson, S. P., \& Devi, S. (2013). Audit committee experts and earnings quality. Corporate Governance: The International Journal of Business in Society, 13(4), 335-351. http://doi.org/10.1108/CG-02-2011-0009

Niu, F. F. (2006). Corporate governance and the quality of accounting earnings: a Canadian perspective. International Journal of Managerial Finance, 2(4), 302-327. http://doi.org/10.1108/17439130610705508

Pollock, T. G., Chen, G., Jackson, E. M., \& Hambrick, D. C. (2010). How much prestige is enough? Assessing the value of multiple types of high-status affiliates for young firms. Journal of Business Venturing, 25(1), 6-23. http://doi.org/10.1016/j.jbusvent.2009.01.003

Rahmawati, R., Rispantyo, R., \& Djamaluddin, S. (2017). Mentoring Function and Quality of Supervisor Auditor Relationship: Organizational Justice as A Mediation. Indonesian Journal of Sustainability Accounting and Management, 1(1), 40-48. http://doi.org/10.28992/ijsam.v1i1.26

Rokhmawati, A., \& Gunardi, A. (2017). Is going green good for profit? Empirical evidence from listed manufacturing firms in Indonesia. International Journal of Energy Economics and Policy, 7(4), 181-192.

Rokhmawati, A., Gunardi, A., \& Rossi, M. (2017). How Powerful is Your Customers' Reaction to Carbon Performance? Linking Carbon and Firm Financial Performance. International Journal of Energy Economics and Policy, 7(6), 85-95.

Saleh, N. M., Iskandar, T. M., \& Rahmat, M. M. (2007). Audit committee characteristics and earnings management: evidence from Malaysia. Asian Review of Accounting, 15(2), 147-163. http://doi.org/10.1108/13217340710823369

Siagian, F. T., \& Tresnaningsih, E. (2011). The impact of independent directors and independent audit committees on earnings quality reported by Indonesian firms. Asian Review of Accounting, 19(3), 192-207. http://doi.org/10.1108/13217341111185128

Sun, J., Lan, G., \& Liu, G. (2014). Independent audit committee characteristics and real earnings management. Managerial Auditing Journal, 29(2), 153-172. http://doi.org/10.1108/MAJ-05-2013-0865

Suteja, J., Gunardi, A., \& Mirawati, A. (2016). Moderating Effect of Earnings Management on the Relationship Between Corporate Social Responsibility Disclosure and Profitability of Banks in Indonesia. International Journal of Economics and Financial Issues, 6(4), 1360-1365.

Widyawati, A. A., \& Anggraita, V. (2013). Pengaruh Konvergensi, Kompleksitas Akuntansi, dan Probabilitas Kebangkrutan terhadap Timeliness dan Manajemen Laba. Jurnal Akuntansi Dan Auditing Indonesia, 17(2), 135-155.

Yunos, R. M., Ahmad, S. A., \& Sulaiman, N. (2014). The Influence of Internal Governance Mechanisms on Accounting Conservatism. Procedia-Social and Behavioral Sciences, 164, 501-507. http://doi.org/10.1016/j.sbspro.2014.11.138

Zgarni, I., Hlioui, K., \& Zehri, F. (2016). Effective audit committee, audit quality and earnings management: Evidence from Tunisia. Journal of Accounting in Emerging Economies, 6(2), 138-155. http://doi.org/10.1108/JAEE-09-2013-0048 